\title{
TERMS OF TRADE AND NON TRADITIONAL EXPORTS: A MICROECONOMETRIC ANALYSIS
}

\section{Ruth Marcela Aparicio}

\begin{abstract}
Since 2004 some economies in Latin America, including Bolivia, have experienced an improvement in their terms of trade. In this research we investigate the causal effect of this improvement on nontraditional exports. We focus on before and after the increase in terms of trade and analyze how this improvement affects export performance. To identify this causal effect we rely on dynamic analysis and we use four different microeconometric techniques: Difference in differences, Kernel propensity score matching, difference in differences combined with propensity score matching, and synthetic control method. Each one of these improves estimation of the counterfactual outcome. Thus, this paper reviews the theory of these impact evaluation methodologies and also analyzes the way in which the theory has developed toward a more systematic methodology to construct the counterfactual. Our estimation results show that nontraditional exports would have increased if these countries had not had improvements in their terms of trade.
\end{abstract}

Keywords: Improvement in Terms of Trade, Nontraditional Exports, Difference in Differences, Propensity Score Matching-Difference in Differences, Synthetic Control Method, Latin American Countries. 